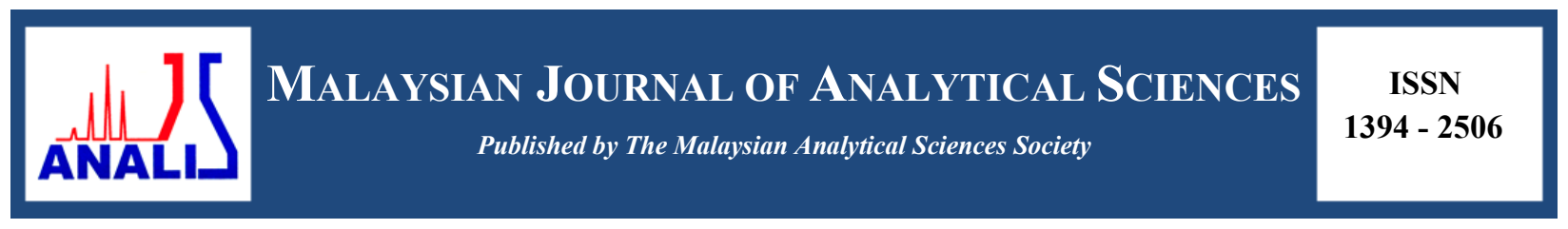

\title{
THERMAL CHARACTERISTICS OF MICROCRYSTALLINE CELLULOSE FROM OIL PALM BIOMASS
}

\author{
(Sifat Terma Mikrokristal Selulosa Daripada Biojisim Tandan Kosong Sawit) \\ Fatin Afifah Ahmad Kuthi ${ }^{1}$, Nor Rabbi’atul 'Adawiyah Norzali ${ }^{1}$, Khairiah Haji Badri ${ }^{1,2 *}$ \\ ${ }^{I}$ School of Chemical Sciences and Food Technology, Faculty of Science and Technology \\ ${ }^{2}$ Polymer Research Center, Faculty of Science and Technology \\ Universiti Kebangsaan Malaysia, 43600 UKM Bangi, Selangor, Malaysia \\ *Corresponding author: kaybadri@ukm.edu.my
}

Received: 10 June 2015; Accepted: 21 July 2016

\begin{abstract}
Extracted cellulose from oil palm empty fruit bunch fiber (OPEFB) was subjected to acid hydrolysis in producing microcrystalline cellulose (MCC). The acid hydrolysis was conducted using $1 \%(\mathrm{v} / \mathrm{v})$ sulfuric acid $\left(\mathrm{H}_{2} \mathrm{SO}_{4}\right)$ at varying temperatures of 120,130 and $140{ }^{\circ} \mathrm{C}$ for an hour. The relationship between the thermal behavior and physical properties was investigated by thermogravimety (TGA/DTG) and differential scanning calorimetry (DSC) as well as x-ray diffractometry (XRD). The hydrolyzed $\mathrm{MCC}$ at $120^{\circ} \mathrm{C}\left(\mathrm{MCC}_{\mathrm{A}}\right)$ showed the highest thermal stability temperature and percentage of crystallinity at $250{ }^{\circ} \mathrm{C}$ and $65.07 \%$ respectively. However, hydrolyzed $\mathrm{MCC}$ at $130{ }^{\circ} \mathrm{C}\left(\mathrm{MCC}_{\mathrm{B}}\right)$ and $140{ }^{\circ} \mathrm{C}\left(\mathrm{MCC}_{\mathrm{C}}\right)$ exhibited low thermal stability temperature at $225^{\circ} \mathrm{C}$ and $220{ }^{\circ} \mathrm{C}$ respectively. The percentage of crystallinity obtained for $\mathrm{MCC}_{\mathrm{B}}$ and $\mathrm{MCC}_{\mathrm{C}}$ was $61.18 \%$ and $60.64 \%$ respectively. This study revealed that the degree of crystallinity for cellulose has positive impact on the thermal degradation temperature of the OPEFB-MCC.
\end{abstract}

Keywords: acid hydrolysis, microcrystalline cellulose, oil palm empty fruit bunch, thermal behavior

Abstrak

Selulosa yang diestrak dari serabut tandan kosong sawit (STKS) dihidrolisis menggunakan asid bagi menghasilkan mikrokristal selulosa (MKS). Hidrolisis berasid dijalankan dengan menggunakan $1 \%(\mathrm{v} / \mathrm{v})$ asid sulfurik $\left(\mathrm{H}_{2} \mathrm{SO}_{4}\right)$ pada suhu yang divariasikan iaitu 120, 130 dan $140^{\circ} \mathrm{C}$ selama sejam. Hubungan antara sifat terma dan sifat fizikal dikaji berdasarkan analisis termogravimetri (TGA/DTG), anlisis kalorimetri imbasan kebezaan (DSC) serta kaedah pembelauan sinar-X (XRD). Peningkatan suhu hidrolisis menunjukkan kesan yang kontra terhadap sifat terma STKS-MKS. MKS yang dihidrolisis pada suhu $120{ }^{\circ} \mathrm{C}\left(\mathrm{MKS}_{\mathrm{A}}\right)$ menunjukkan suhu kestabilan terma dan peratus kehabluran yang paling tinggi iaitu masing-masing pada $250{ }^{\circ} \mathrm{C}$ dan $65.07 \%$. MKS yang dihdrolisis pada $130{ }^{\circ} \mathrm{C}\left(\mathrm{MKS}_{\mathrm{B}}\right)$ dan $140{ }^{\circ} \mathrm{C}\left(\mathrm{MKS}_{\mathrm{C}}\right)$ mempamerkan suhu kestabilan terma yang rendah iaitu masing masing pada suhu $225^{\circ} \mathrm{C}$ dan $220^{\circ} \mathrm{C}$. Peratus kehabluran yang diperoleh bagi $\mathrm{MKS}_{\mathrm{B}}$ dan $\mathrm{MKS}_{\mathrm{C}}$ masing-masing adalah $61.18 \%$ dan $60.64 \%$. Kajian ini memberi indikasi bahawa darjah kehabluran selulosa memberi kesan positif kepada suhu degradasi terma TKKS-MKS.

Kata kunci: hidrolisis berasid, mikrokristal selulosa, serabut tandan kosng kelapa sawit, sifat terma

\section{Introduction}

Oil palm empty fruit bunch (OPEFB) is one of the major agricultural crops generated from palm oil mills in Malaysia. This biomass which is a carbohydrates polymer; comprised of cellulose and hemicellulose and also aromatic polymer called lignin. Despite these three major components, OPEFB also consists of few minor 
components such as extractives, inorganic compound and ash [1-3]. Previous study shows that the content of cellulose, hemicellulose and lignin in OPEFB are $44.48 \%, 27.00 \%$ and $17.00 \%$ respectively [4]. Figure 1 represents lignocellulosic material structures of the plant cell wall [5].

As a boundless renewable resource, cellulose has a potential on producing environmental friendly and biocompatible products. Cellulose, a glucan polymer that made up from D-glucopyranose units and joined together by $\beta$ - $(1 \rightarrow 4)$ - glucosidic bonds [6-8]. Naturally, cellulose resembles in micro fibrils form and composes of crystalline and amorphous region. The 'composite ribbon' micro fibrils bundles are linked by hydrogen bond between the hydroxyl groups and oxygen [9-11]. All native cellulose has been classified as cellulose type I [6]. Studies showed that cellulose type I has intra-molecular hydrogen bond for $\mathrm{O}(2) \mathrm{H} \cdots \mathrm{O}(6)$ and $\mathrm{O}(3) \mathrm{H} \cdots \mathrm{O}(5)$ and the inter-molecular hydrogen bond for $\mathrm{O}(6) \mathrm{H} \cdots \mathrm{O}\left(3^{\prime}\right)$ as shown in figure 2 [12-13].

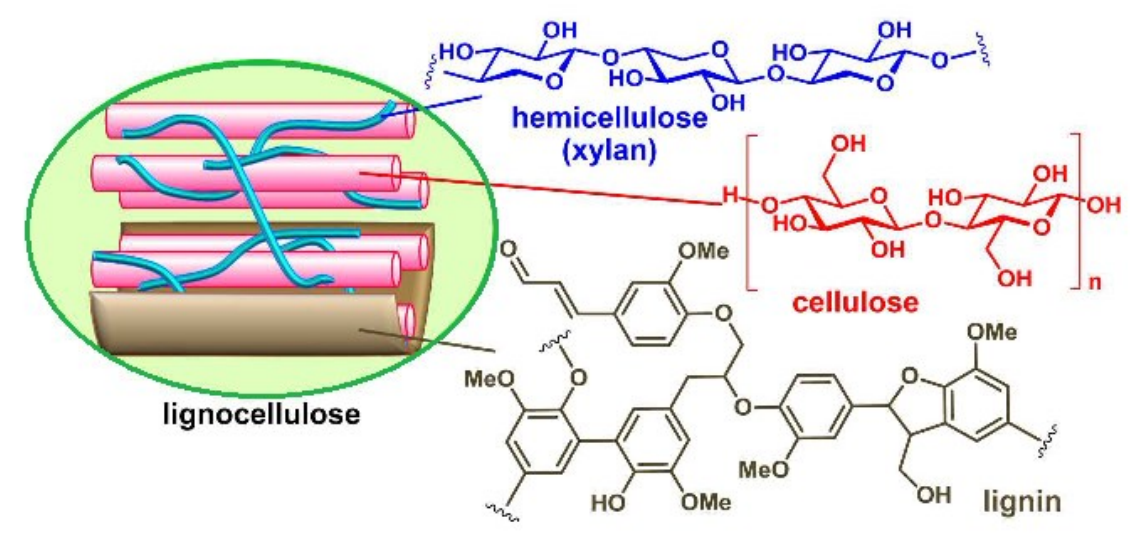

Figure 1. Schematic diagram of lignocellulosic material and their structure

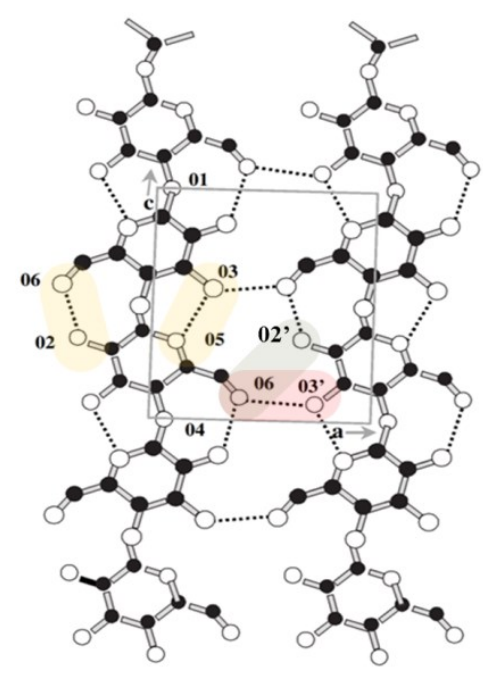

Figure 2. Inter-molecular and intra-molecular hydrogen bonding in cellulose type I 
Microcrystalline cellulose (MCC) is defined as a purified, partially depolymerized non-fibrous form of cellulose. MCC is produced by treating cellulose acquired from plant materials using conventional method that is acid hydrolysis. Commercially MCC is produced by woody plants and purified cotton. MCC is white in color, odorless and tasteless crystalline powder. The chemical and physical properties such as crystallinity, moisture content, surface area, molecular weight and porosity are varied depend eloquently on the characteristic of the raw materials and hydrolysis conditions. Commercial MCC produced nowadays have different physicochemical and thermal properties which lead to different functional parameters and applications [7, 14, 15].

MCC is used as a value-added product in food processing, pharmaceutical and cosmetic industries [16]. Today, MCC also being used in producing glucose in order to generate 5-hydroxymethyl furfural (HMF) and levulinic acid as a desirable precursor for catalytic conversion into chemicals and hydrocarbon fuels [17]. Thermal analysis is a technique to prevail the thermal behavior of a material under various conditions. Thermal analysis also determines the changes of a material by noting the temperature at which thermal halt occurred $[18,19]$. Azubuike and Okhamafe stated that TGA and DSC analysis also helped to clarify the stability, compatibility and transition of phase of the excipients [7]. In this research, the thermal behavior of MCC from OPEFB was investigated using thermogravimetric analysis (TGA), differential thermal analysis (DTA) and differential scanning calorimetry (DSC). These were employed in order to facilitate the understanding of the possible chemical reactions for the depolymerization of MCC. The MCC was produced by using cellulose extracted from OPEFB through acid hydrolysis at mild concentration and varying hydrolysis temperature of 120,130 and $140{ }^{\circ} \mathrm{C}$. This work also compared the MCC crystallinity data from X-ray diffraction technique with the thermal stability property.

\section{Materials}

\section{Materials and Methods}

Oil palm empty fruit bunch fiber (OPEFB) was kindly supplied by Seri Ulu Langat Palm Oil Mills Sdn Bhd, Selangor, Malaysia. The fiber was ground and sieved to obtain fiber size ranging from 315 to $500 \mu \mathrm{m}$. Chemicals used for $\alpha$-cellulose extraction and acid hydrolysis were ethanol $\left(\mathrm{C}_{2} \mathrm{H}_{5} \mathrm{OH} ; 95 \%\right.$ purity, John Kollin Chemicals, UK), sodium chlorite, $\left(\mathrm{NaClO}_{2} ; 80 \%\right.$ purity, Sigma Aldrich, USA) and hydrogen peroxide, $\left(\mathrm{H}_{2} \mathrm{O}_{2} ; 30-32 \%\right.$ purity, Friendemann Schmidt Chemical, Germany). Acetic acid $\left(\mathrm{CH}_{3} \mathrm{COOH} ; 99.5 \%\right.$ purity), sodium hydroxide pellet $\left(\mathrm{NaOH} ; 99 \%\right.$ purity), sulfuric acid $\left(\mathrm{H}_{2} \mathrm{SO}_{4} ; 98-99 \%\right.$ purity) and toluene $\left(\mathrm{C}_{7} \mathrm{H}_{8} ; 99.5 \%\right)$ were purchased from Systerm Sdn Bhd, Selangor, Malaysia. Commercial cellulose microcrystalline powder (Sigma Aldrich, USA) was used as the standard reference.

\section{Method}

The prepared OPEFB fibers were dried in a conventional oven at $105{ }^{\circ} \mathrm{C}$ for 24 hours and the moisture content was determined. Alcohol-benzene extraction was carried out to remove the extractives such as wax, oil and inorganic substances. This was carried out using ethanol and toluene mixture as the solvent at the ratio of 1:2 by volume for 8 hours following TAPPI T204 cm-97 (Alcohol-benzene solubility of pulp) [20]. The extracted fibre undergone bleaching process to remove lignin by mixing with $25 \mathrm{~mL}$ of $10 \%(\mathrm{v} / \mathrm{v}) \mathrm{CH}_{3} \mathrm{COOH}$ aqueous solution and $6 \mathrm{~g}$ of $\mathrm{NaClO}_{2}$ subsequently under boiling water bath [21]. The mixture was filtered using hardened ash less filter paper (540, Whatman) via Buchner funnel. The whitish yellow filter cake was dried. The filter cake was treated with 75 $\mathrm{mL}$ of $17.5 \% \mathrm{NaOH}$ aqueous solution in a water bath $\left(20^{\circ} \mathrm{C}\right)$. The suspension was filtered and the filter cake was rinsed with $8.3 \% \mathrm{NaOH}$ aqueous solution followed by $650 \mathrm{~mL}$ cold distilled water in order to remove the hemicellulose leaving the $\alpha$-cellulose in the filter cake. The extracted sample was dried at $105{ }^{\circ} \mathrm{C}$ for 24 hours.

Microcrystalline cellulose (MCC) was produced by acid hydrolysis reaction from the dried sample following method proposed by Soom et al. [22]. The reaction was performed by using 1\% (v/v) $\mathrm{H}_{2} \mathrm{SO}_{4}$ diluted solution for an hour at varying temperatures of 120,130 and $140{ }^{\circ} \mathrm{C}$. The ratio of extracted sample to acid solution was fixed at 1:10. After the reaction was completed, the MCC was rinsed with cold distilled water until it reached $\mathrm{pH} 7$ [7]. The MCC was soaked in $10 \%(\mathrm{v} / \mathrm{v}) \mathrm{H}_{2} \mathrm{O}_{2}$ diluted solution for $90 \mathrm{~min}$ at $60^{\circ} \mathrm{C}$ for bleaching purpose [23]. The yield was dried in the oven before further characterization. 


\section{Characterizations: X-ray diffraction (XRD)}

$\mathrm{X}$-ray diffraction (XRD) analysis was carried out using Bruker X-ray diffractometer (model D8-Advance). The radiation used was $\mathrm{Cu}-\mathrm{K} \alpha 1$ at $1.514 \AA$. All samples were analysed at $2 \theta$ of $5^{\circ}$ to $60^{\circ}$ with the step size of $0.025^{\circ} / \mathrm{s}$. The percentage of crystallinity (CrI) was calculated using the following equation (1) [24]:

$$
\mathrm{CrI}, \%=\frac{\mathrm{Sc}}{\mathrm{St}} \times 100
$$

where Sc is the area of all crystalline peak and $\mathrm{St}$ is the total area including non-crystalline fraction

\section{Thermogravimetric analysis/Differential thermal analysis (TGA/DTA)}

Thermogravimetric analysis (TGA) and differential thermal analysis (DTA) were performed using Mettler Toledo model TGA/SDTA $518^{\mathrm{e}}$ to analyze the thermal behavior of OPEFB, MCC and CMCC samples. The samples were heated from 30 to $600{ }^{\circ} \mathrm{C}$ with heating rate of $10^{\circ} \mathrm{C} \cdot \mathrm{min}^{-1}$ under nitrogen gas atmosphere [25].

\section{Differential scanning calorimetry}

The differential scanning calorimetry (DSC) of the materials was analyzed using Mettler Toledo model DSC $822^{\mathrm{e}}$. It was analyzed under nitrogen gas blanket at a flow rate of $20 \mathrm{~mL} \cdot \mathrm{min}^{-1}$. The temperature was programmed at 30 to $250^{\circ} \mathrm{C}$ with heating rate of $10^{\circ} \mathrm{C} \cdot \mathrm{min}^{-1}$.

\section{X-ray diffraction}

\section{Results and Discussion}

The X-ray diffraction (XRD) patterns for all samples are as shown in Figure 3. The main reflection at $2 \theta=15.0^{\circ}$, $18.0^{\circ}, 22.6^{\circ}$ and $35^{\circ}$ were observed for all samples $[7,11]$. The lattice planes for these reflections were at $101,10 \overline{1}$, 002 and 040 respectively [7,12]. The free hydroxyl groups present in cellulose are contributed to the rise of various ordered crystal arrangements. This is due to the formation of inter-molecular and intra-molecular hydrogen bonds within the fibrils [26]. Reflections at $15.0^{\circ}, 18.0^{\circ}, 22.6^{\circ}$ and $35^{\circ}$ are typical diffraction signals of polymorph type I which commonly occur in native cellulose [7].

There are two types of natural occurring cellulose called $\mathrm{I}_{\alpha}$ and $\mathrm{I}_{\beta}$. Cellulose $\mathrm{I}_{\alpha}$ usually found in bacterial and algae celluloses whereas cellulose $I_{\beta}$ is found in higher plant. $I_{\alpha}$ and $I_{\beta}$ exhibited as triclinic and monoclinic unit cells respectively [27]. The changes from polymorph type I to polymorph type II can be seen in the $\alpha$-cellulose sample. A shoulder around $2 \theta$ of $20.4^{\circ}$ was observed after alkali treatment was carried out. MCC-OPEFB samples also showed the coexistence of both polymorph types I and II. Two shoulders at $2 \theta$ of $20.4^{\circ}$ and $12.5^{\circ}$ with their respective lattice planes of 110 and $11 \overline{0}$ indicate that acid hydrolysis also contributed in the changes of polymorph type [7, 28].

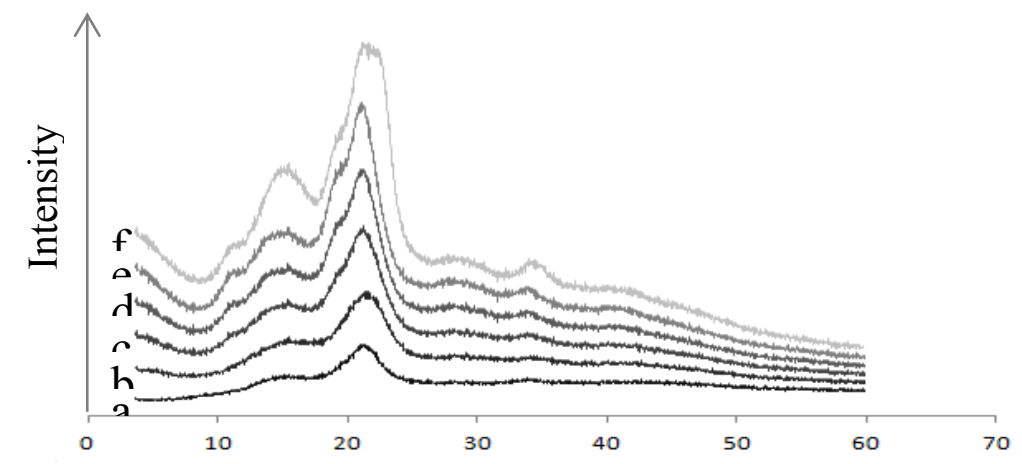

$2 \theta$

Figure 3. X-ray diffraction patterns of (a) OPEFB; (b) $\alpha$-cellulose; (c) $\mathrm{MCC}_{\mathrm{A}}$; (d) $\mathrm{MCC}_{\mathrm{B}}$; (e) $\mathrm{MCC}_{\mathrm{C}}$ and (f) $\mathrm{CMCC}$ 
The crystallinity index, CrI (\%) of OPEFB, $\alpha$-cellulose, OPEFB-MCC and CMCC are listed in Table 1. In this study, the crystallinity index was calculated using deconvolution method or curve fitting method. In this method, calculation of $\mathrm{CrI}$ is based on the ratio of all crystalline area to the total area [12, 29].

Table 1. Percentage of crystallinity of OPEFB, $\alpha$-cellullose, OPEFB-MCC and CMCC

\begin{tabular}{lc}
\hline Samples & Crystallinity, CrI(\%) \\
\hline OPEFB & 43.24 \\
a-cellulose & 44.78 \\
MCC $_{A}$ & 65.07 \\
MCC $_{B}$ & 61.18 \\
MCC $_{C}$ & 60.64 \\
CMCC & 76.19 \\
\hline
\end{tabular}

The crystallinity index increased upon extraction of the $\alpha$-cellulose. This is possible due to the breakdown of amorphous regions contributed by hemicellulose and lignin [30,31]. Significant increments of crystallinity index were observed for the acid hydrolyzed samples. This is due to the removal of amorphous part in $\alpha$-cellulose resulted by the scissoring effect of glycosidic linkages [30]. Higher crystallinity index for CMCC sample was due to the characteristics of the raw material and its hydrolysis condition [14].

\section{Thermal Properties via thermogravimetry analysis (TGA) and differential thermal analysis (DTA)}

Figure 3 shows the thermograms of TGA and DTA analyses performed on OPEFB, $\alpha$-cellulose, OPEFB-MCC and CMCC. Table 2 represents the numerical data from TGA and DTA analyses. The initial weight loss for all samples except $\mathrm{CMCC}$ at temperature around $100^{\circ} \mathrm{C}$ was attributed to the evaporation of water or moisture $[26,31,32]$. The onset temperature of OPEFB was the lowest compared to other samples. Poletto et al. stated that degradation of hemicellulose which occurs at temperature between 180 to $350^{\circ} \mathrm{C}$ [26]. A shoulder in OPEFB DTA curve at $280{ }^{\circ} \mathrm{C}$ was suspected belong to hemicellulose since it degrades at a lower temperature compared to lignin and cellulose.

Among the OPEFB-MCC, $\mathrm{MCC}_{\mathrm{A}}$ showed the highest onset temperature $\left(250^{\circ} \mathrm{C}\right)$ followed by $\mathrm{MCC}_{\mathrm{B}}$ and $\mathrm{MCC}_{\mathrm{C}}$. This is due to the high crystallinity of cellulose in $\mathrm{MCC}_{\mathrm{A}}$. The reorientation of the crystals in cellulose promotes to arise in onset temperature of degradation [33]. According to Poletto et al. (2012), the degradation of cellulose occurs at maximum temperature, $\left(\mathrm{T}_{\max }\right)$ of $350{ }^{\circ} \mathrm{C}$. At this temperature, the scissoring of glycosidic linkage in cellulose happens [26]. The increase in the hydrolytic values lowers both the molecular weight and the $T_{\max }$ values. This is attributable to the hydrolytic effect of the crystalline part of the cellulose along with the amorphous hydrolysis [30, 33]. The high onset temperature was observed in CMCC $\left(295^{\circ} \mathrm{C}\right)$ was due to its high percentage of crystallinity [11]. 
Fatin Afifah et al: THERMAL CHARACTERISTICS OF MICROCRYSTALLINE CELLULOSE FROM OIL PALM BIOMASS

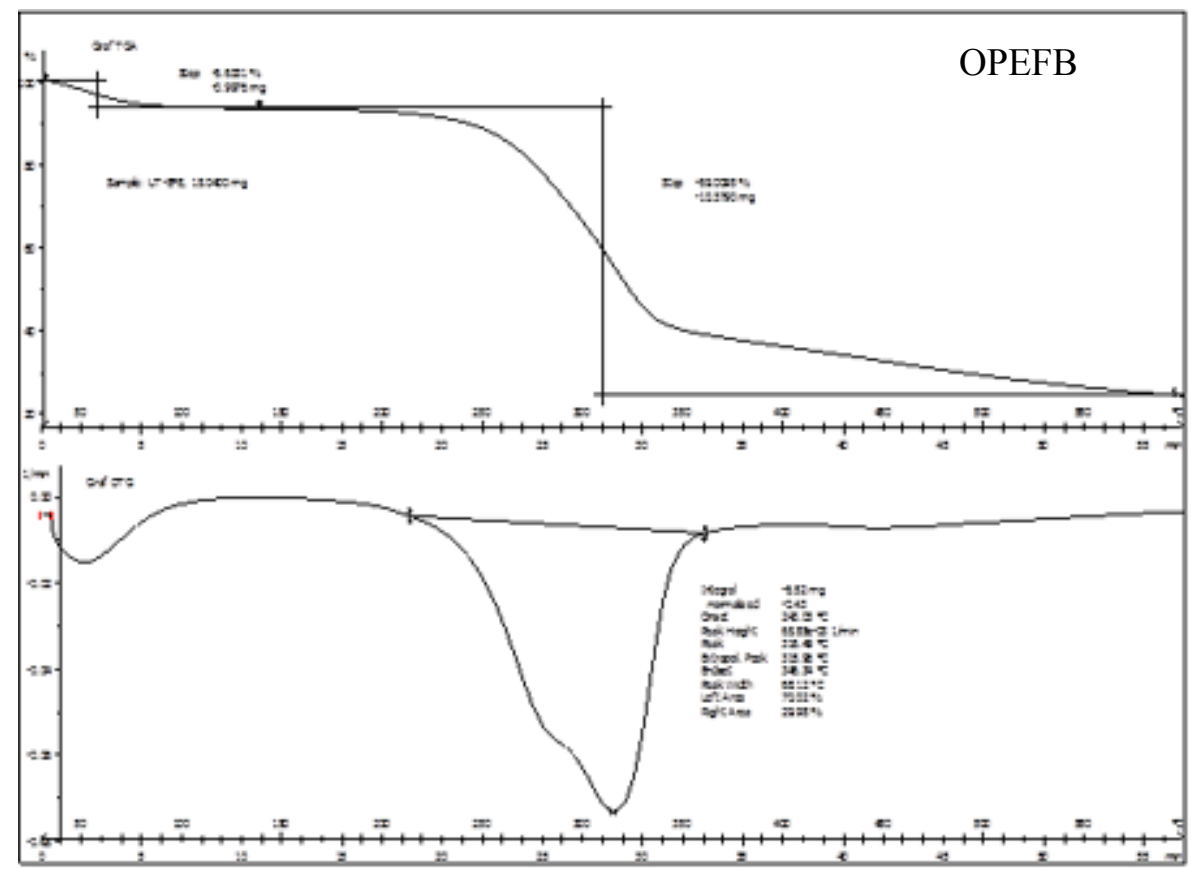

Figure 4 (a). The TGA/DTA curves of OPEFB

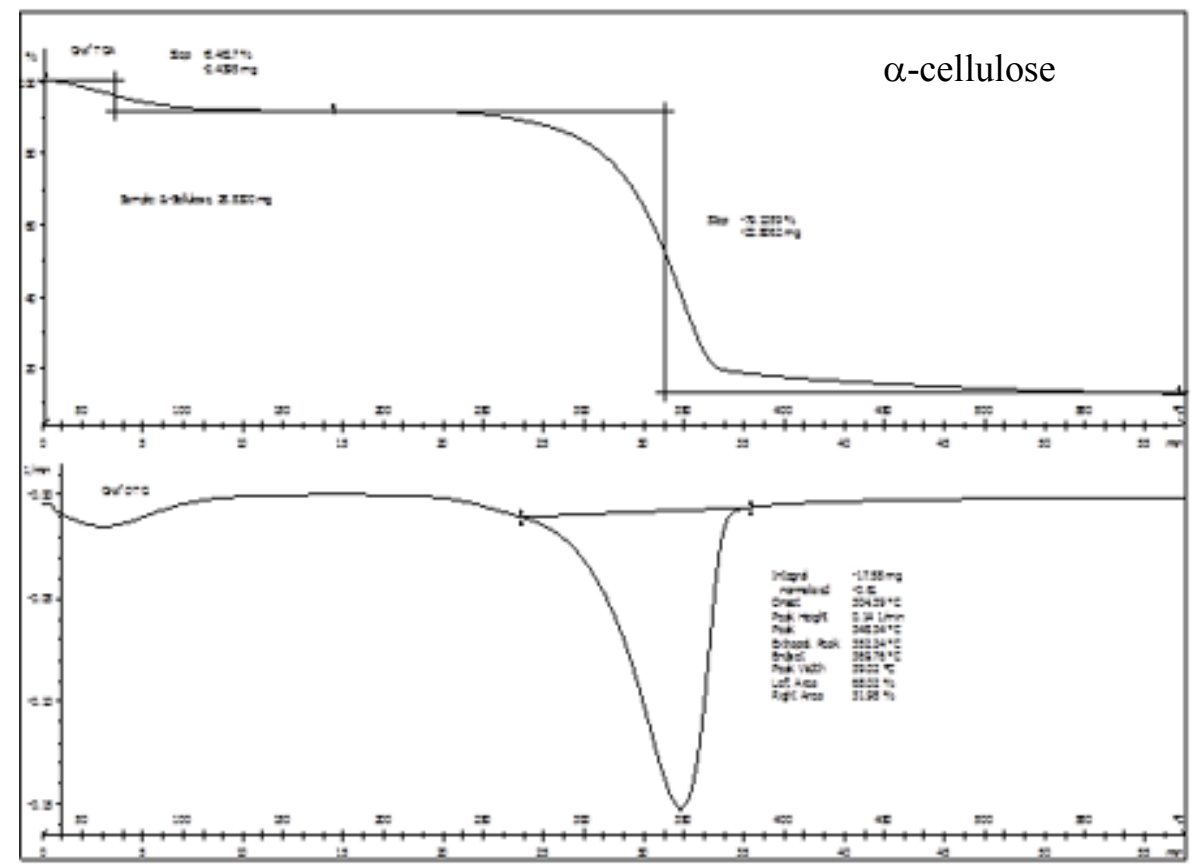

Figure 4 (b). The TGA/DTA curves of $\alpha$-cellulose 


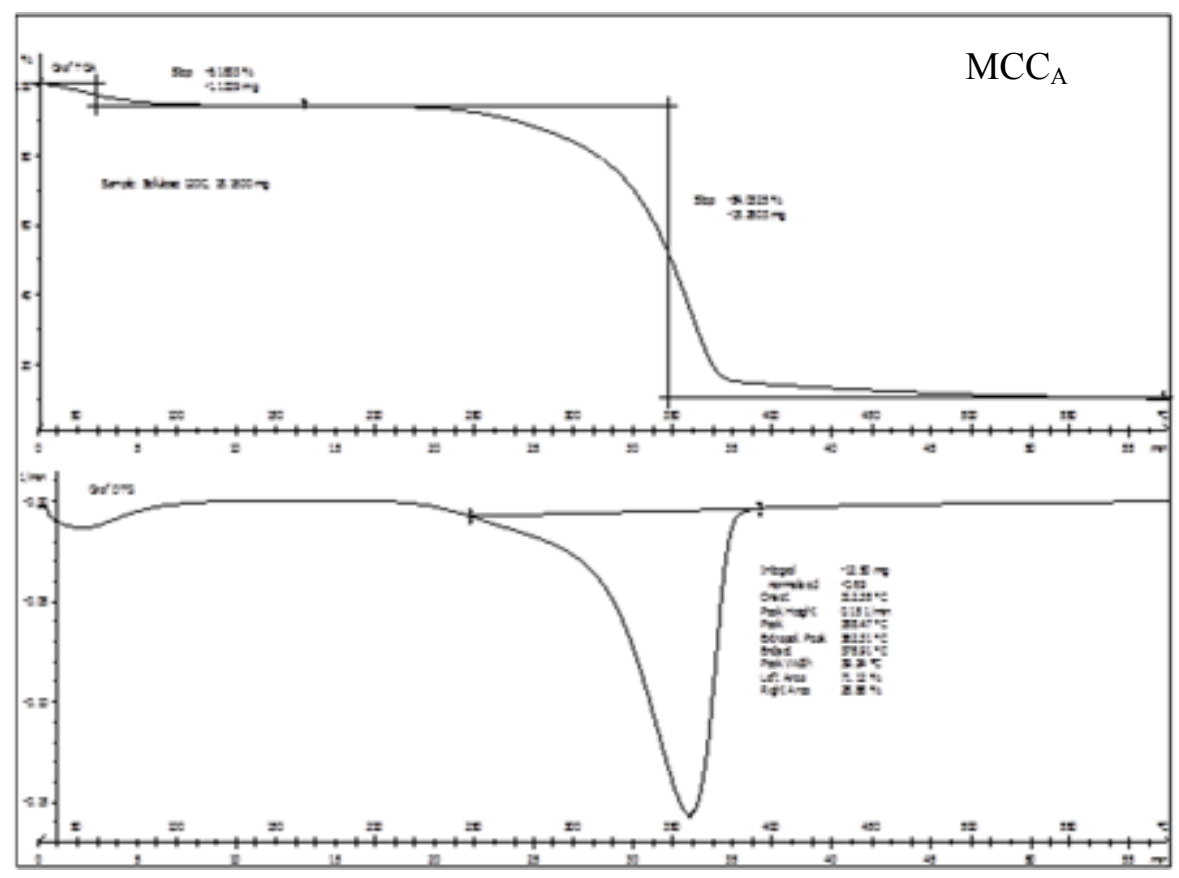

Figure 4 (c). The TGA/DTA curves of $\mathrm{MCC}_{\mathrm{A}}$

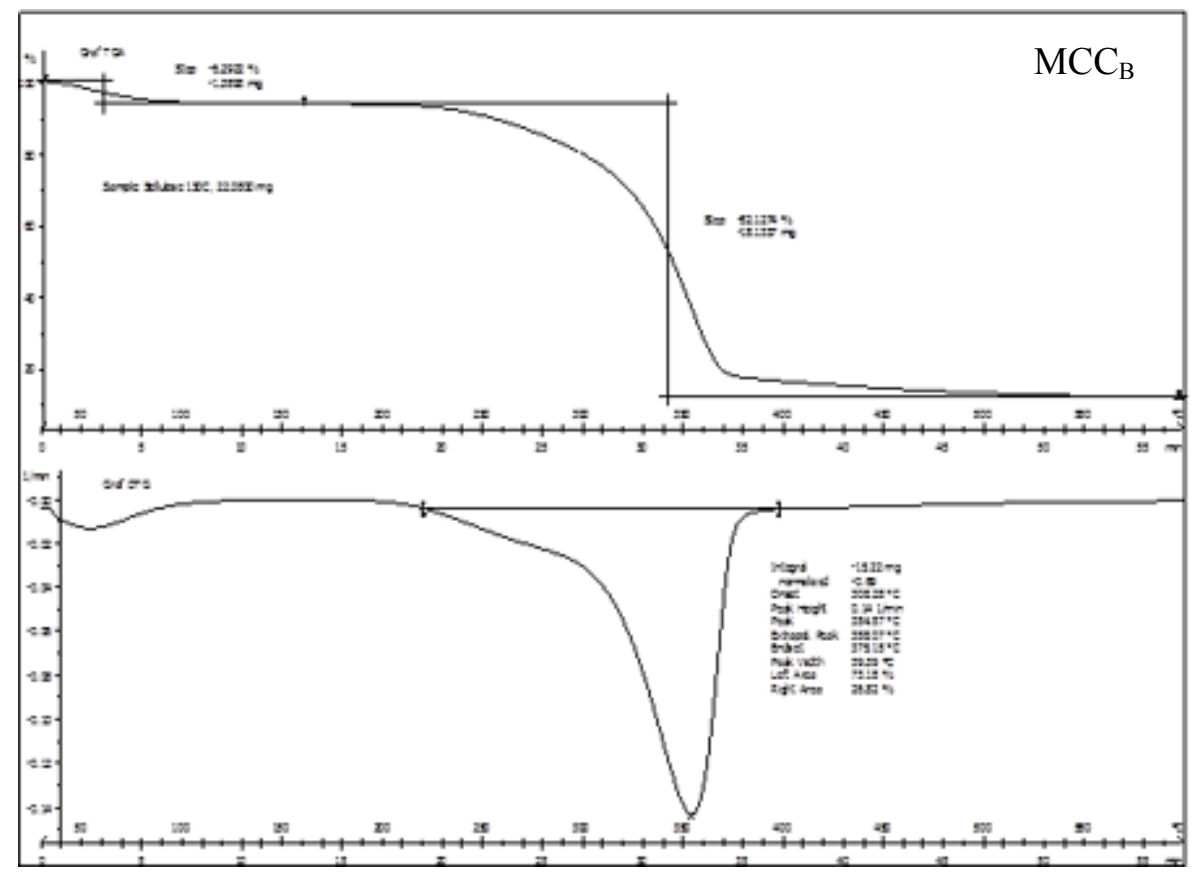

Figure 4 (d). The TGA/DTA curves of $\mathrm{MCC}_{\mathrm{B}}$ 
Fatin Afifah et al: THERMAL CHARACTERISTICS OF MICROCRYSTALLINE CELLULOSE FROM OIL PALM BIOMASS

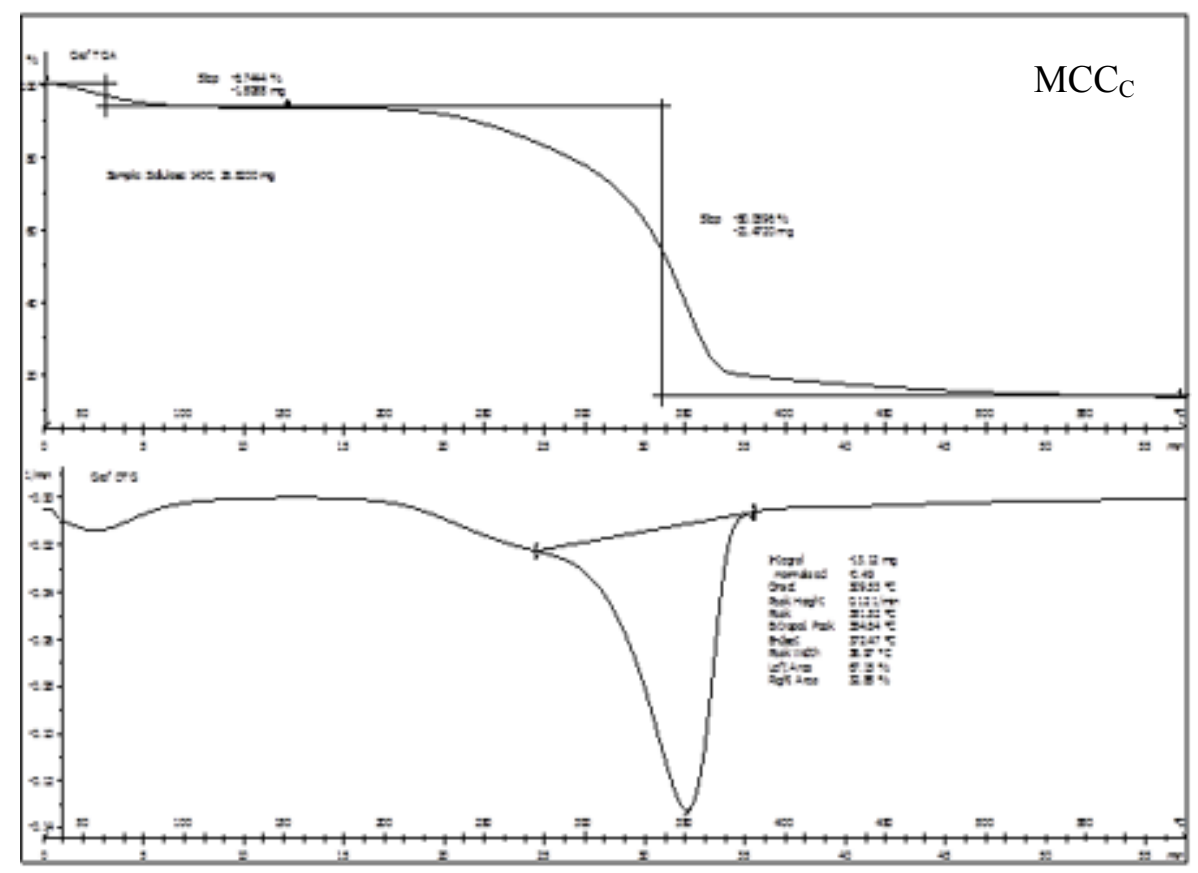

Figure 4 (e). The TGA/DTA curves of $\mathrm{MCC}_{\mathrm{C}}$

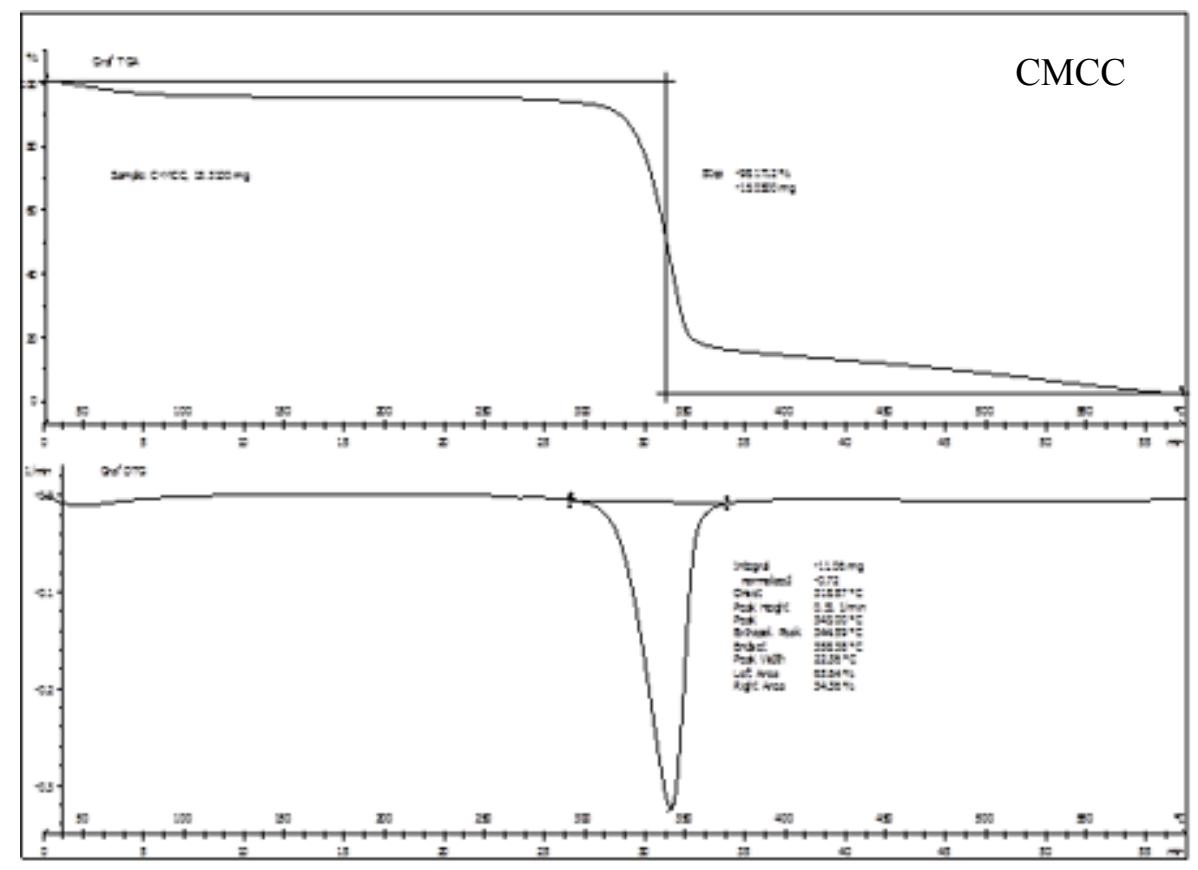

Figure 4 (f). The TGA/DTA curves of CMCC 


\section{Differential scanning calorimetry (DSC)}

The glass transition temperature, $\mathrm{T}_{\mathrm{g}}$ was tabulated in Table 2 . The $\mathrm{T}_{\mathrm{g}}$ value observed in OPEFB was lower compared to $\alpha$-cellulose due to the low molecular weight of hemicellulose in OPEFB. Hemicellulose is enriched with many branched structures and also polyose chains [25]. This causes the chain mobility in OPEFB occur at lower temperature. The broad $\mathrm{T}_{\mathrm{g}}$ peak on OPEFB was due to the presence of hemicellulose and lignin whereas the broad $\alpha$-cellulose $T_{g}$ peak was contributed by the amorphous cellulose. Based on the $T_{g}$ obtained for the OPEFB-MCC, $\mathrm{MCC}_{\mathrm{A}}$ showed high $\mathrm{T}_{\mathrm{g}}$ compared to $\mathrm{MCC}_{\mathrm{B}}$ and $\mathrm{MCC}_{\mathrm{C}}$. This is due to the acid hydrolysis of the crystalline cellulose at high temperature as discussed earlier. $\mathrm{CMMC}$ has the lowest $\mathrm{T}_{\mathrm{g}}$ due to its initial physical condition which is powdered form.

Table 2. Thermal properties obtained from TGA and DSC analysis of all samples studied

\begin{tabular}{lcccc}
\hline Samples & $\begin{array}{c}\mathbf{T}_{\text {onset }} \\
\left({ }^{\circ} \mathbf{C}\right)\end{array}$ & $\begin{array}{c}\mathbf{T}_{\text {max }} \\
\left({ }^{\circ} \mathbf{C}\right)\end{array}$ & $\begin{array}{c}\mathbf{T}_{\mathbf{g}} \\
\left({ }^{\circ} \mathbf{C}\right)\end{array}$ & $\begin{array}{c}\text { Weight loss } \\
\mathbf{( \% )}\end{array}$ \\
\hline OPEFB & 215 & 315 & 182 & 75.64 \\
a-cellulose & 250 & 349 & 187 & 87.57 \\
MCC $_{\mathrm{A}}$ & 250 & 360 & 178 & 90.22 \\
$\mathrm{MCC}_{\mathrm{B}}$ & 225 & 355 & 171 & 88.42 \\
$\mathrm{MCC}_{\mathrm{C}}$ & 220 & 350 & 171 & 86.80 \\
$\mathrm{CMCC}$ & 295 & 345 & 168 & 98.17 \\
\hline
\end{tabular}

\section{Conclusion}

The thermal behavior of microcrystalline cellulose from oil palm empty fruit bunch (OPEFB) has been investigated. Acid hydrolysis has significantly increased the thermal stability of the OPEFB. However, higher hydrolysis temperature reduced the thermal stability. The $\mathrm{MCC}_{\mathrm{A}}$ showed the highest thermal stability and highest percentage of crystallinity.

\section{Acknowledgement}

The authors gratefully acknowledge School of Chemical Sciences and Food Technology and Polymer Research Center (PORCE), Faculty of Science and Technology, Universiti Kebangsaan Malaysia for providing the working space and facilities and also to the Ministry of Higher Education (MOHE) for the Exploratory Research Grant Scheme (ERGS) with code no. ERGS/1/2013/STG01/UKM/02/2.

\section{References}

1. Sreekala, M. S., Kumaran, M. G. and Thomas, S. (1997). Oil palm fibers: Morphology, chemical composition, surface modification and mechanical properties. Journal of Applied Polymer Science, 66: $821-835$.

2. Law, K. N., Daud, W. R. W. and Ghazali, A. (2007). Morphological and chemical mature of fibers strands of oil empty fruit bunch (OPEFB). Bioresources, 2(3): $352-362$.

3. Abdul Khalil, H. P. S., Alwani, M. S., Ridzuan, R., Kamarudin, H. and Khairul, A. (2008). Chemical composition, morphological characteristic and cell wall structure of Malaysian oil palm fibers. PolymerPlastics Technology and Engineering, 47: 273 - 280.

4. Kuthi, F. A. A. and Badri, K. (2014). Effect of cooking temperature on the crystallinity of acid hydrolysed-oil palm cellulose. AIP Conference Proceedings, 1614: 456 - 462.

5. Kobayashi, H. and Fukuoka, A. (2013). Synthesis and utilisation of sugar compounds derived from lignocellulosic biomass. Green Chemistry, 5(7): 1740 - 1763.

6. Rowell, R. M., Pettersen, R., Han, J. S., Rowell, J. S. and Tshabalala, M.A. (2005). Cell wall chemistry, Rowell, R. M, Handbook of wood chemistry and wood composites, CRC Press, Florida. 
7. Azubuike, C. P. and Okhamafe, A. O. (2012). Physicochemical, spectroscopic and thermal properties of microcrystalline cellulose derived from corn cobs. International Journal of Recycling of Organic Waste in Agriculture, 1(9): 1 - 7.

8. Frone, A. N., Panaitescu, D. M. and Donescu, D. (2011). Some aspects concerning the isolation of cellulose micro and nano-fibers. U.P.B. Scientific Bulletin, 73(2): 133 - 152.

9. Nishiyama, Y. (2009). Structure and properties of the cellulose microfibril. Journal of Wood Science, 55: 241 249.

10. Kuthi, F. A. A., Badri, K. dan Azman, M. A. (2014). X-ray diffraction patterns of oil palm empty fruit bunch fibers with varying crystallinity. Advanced Materials Research, 1087: 321 - 328.

11. Haafiz, M. K. M., Hassan, A., Zakaria, Z. and Inuwa, I. M. (2014). Isolation and characterization of cellulose. Carbohydrate Polymers, 103: 119 - 125.

12. Yuan, L., Wan, J., Ma, Y., Wang, Y., Huang, M. and Chen, Y. (2013). The content of different hydrogen bond models and crystal structure of Eucalyptus fibers during beating, BioResources, 8(1): 717 - 734 .

13. Kahar, P. (2013). Synergistic effects of pretreatment process on enzymatic digestion of rice straw for efficient ethanol fermentation, Petre, M., Environmental Biotechnology-New Approached Prospective Applications, InTech publisher: pp. 65.

14. Adel, A. M., El-Wahab, Z. H., Ibrahim, A. A and Al-Shemy, M. T. (2011). Characterization of microcrystalline cellulose prepared from lignocellulosic materials. Part II: Physicochemical properties. Carbohydrate Polymers, 83: $676-687$.

15. Trache, D., Donnot, A., Khimeche, K., Benelmir, R. and Brosse, N. (2014). Physico-chemical properties and thermal stability of microcrystalline cellulose isolated from Alfa fibers. Carbohydrate Polymers, 104: 223 230.

16. Chauhan, R. S., Sapkal, V. S., Sapkal, V. S. and Zamre, G. S. (2009). Microcrystalline cellulose from cotton rags (waste from garment and hosiery industries). Journal Chemical Sciences, 7(2): $681-688$.

17. Wyman, C. E. (2013). Introduction. aqueous pretreatment of plant biomass for biological and chemical conversion to fuels and chemicals, First Edition, Johm Wiley \& Sons Ltd.: pp. 1-15.

18. Adel, A. M., El-Wahab, Z. H., Ibrahim, A. A. and Al-Shemy, M. T. (2010). Characterization of microcrystalline cellulose prepared from lignocellulose materials, Part I: Acid hydrolysis. Bioresources Technology, 101: 4446 - 4455.

19. Barneto, A. G., Carmona, J. A., Alfonso, J. E. and Serrano, R. S. (2010). Simulation of the thermogravimetry analysis of three non-wood pulps. Bioresources Technology, 101: 3220 - 3229.

20. Anon. (1997). Alcohol-benzene solubility of pulp. TAPPI Testing Procedure (TAPPI T204 cm-97) USA.

21. Browning, B. L. (1967). Methods of wood chemistry, J. Wiley and Sons, New York: pp. $394-396$.

22. Soom, R. M., Aziz, A. A., Hassan, W. H. W. and Top, A. G. M. (2009). Solid state characteristics of microcrystalline cellulose from oil palm empty fruit bunch fibre. Journal of Oil Palm Research, 21: 613 - 620.

23. Nazir, M. S., Wahjoedi, B. A., Yussof, A.W. and Abdullah, M. A. (2013). Eco-friendly extraction and characterization of cellulose from oil palm empty fruit bunches. BioResources, 8: $2161-2172$.

24. Ciolacu, D., Ciolacu, F. and Popa,V. I. (2011). Amorphous cellulose- structure and characterization. Cellulose of Chemistry and Technology, 45: $13-21$.

25. Harun, N. A. F., Baharuddin, A. S., Zainudin, M. H. M, Bahrin, E. K., Naim, M. N. and Zakaria, R. (2013). Cellulose production from treated oil palm empty fruit bunch degradation by locally isolated Thermobifida fusca. Bioresources, 8(1): $676-687$.

26. Poletto, M., Zattera, A. J., Forte, M. M. C. and Santara, R. M. C. (2012). Thermal decomposition of wood: Influence of wood components and cellulose crystallite size. Bioresource Technology, 109: $148-153$.

27. Poletto, M., Junior, H. L. O. and Zattera, A. J. (2014). Native cellulose: structure, characterization and thermal properties. Materials, 7: $6105-6119$.

28. Rojas, J. (2013). Effect of polymorphism on the particle and compaction properties of microcrystalline cellulose, InTech Open: pp. $27-46$.

29. Terinte, N., Ibbett, R. and Schuster, K. C. (2011). Overview on native cellulose and microcrystalline cellulose I structure studied by x-ray diffraction. Lenzinger Berichte, 89: 118 - 131.

30. Haafiz, M. K. M., Eichhorn, S. J., Hassan, A. and Jawaid, M. (2013). Isolation and characterization of microcrystalline cellulose from oil palm biomass residue, Carbohydrate Polymers, 93: 628 - 634 . 
31. Chan, C. H., Chia, C. H., Zakaria, Ahmad, S. I. and Dufresne, A. (2013). Production and characterisation of cellulose and nano-crystalline cellulose from kenaf core wood. BioResources, 8: 785 - 794.

32. Peng, Y., Gardner, D. J., Han, Y., Kiziltas, A., Cai, Z. and Tshabalala, M. A. (2013). Influence of drying method on the material properties of nanocellulose I: thermostability and crystallinity. Cellulose, 20(5): 2379 2392.

33. Mandal, A. and Chakrabarty, D. (2011). Isolation of nanocellulose from waste sugarcane bagasse (SCB) and its characterization. Carbohydrate Polymers, 86: 1291 - 1299. 